\title{
下垂體前葉、・副腎皮質系ホルモンの血清 蛋白像に對する作用に關する臨床觀測
}

\author{
神戶醫科大學第 2 內科學教空 (指導 竹田正次教授) \\ 岸田輝二
}

本論交の婻旨は第25回日本內分泌馟會（昭和 27 年 4 月）席上で報告した。

\section{I 緒 言}

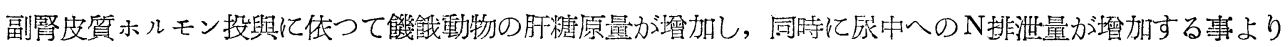
Long 等 $(1940)^{1}$ は該ホルモンが蛋白汃らの糖生成過程に關係を有するという概念に到達し，此概念は其


想像々難くない.

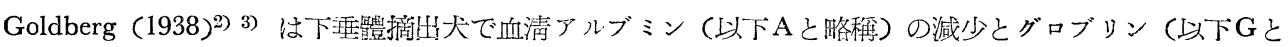

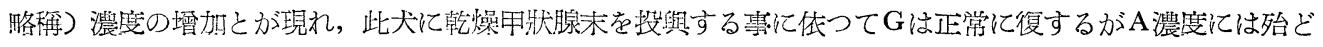


機骷低下に歸した。

其後 Levine 攻び Leathem (1942)4) は此事實を鼠に就て thyroxin を用いて確認したが，更に ACE 又 は DC の普通量で治潦すると甲狀腺ホルモンの場合とは逆にAの減少は著明に卯制されるがG對しては 殆ど影響を認めなかつたので氏等は鼠に於ては血清 $\mathrm{A}$ 量は副腎皮質に依つて維持せられ，G量は甲狀脉機能 亿關連すると云う結論记到達した。

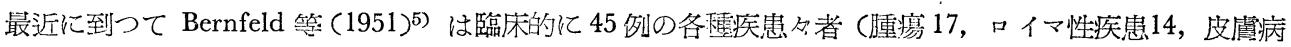

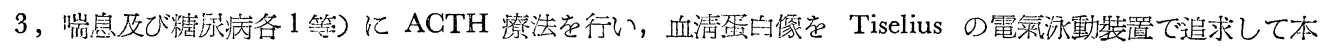
劑治療中には 6 例に於て $\beta-G$ 減少， 5 例に於て休藥後著堙するのを認め，佾 $\beta-G$ 減少を認めた症例では


見られたのは僅に僅に各1例であつたと㕕う。但し ACTH 療法中に $\beta-G$ が減少し，其後徐々に增加す るのは Tiselius 泳動傢では lipoproteins の一部分が $\beta$-G. group にあるから，從つて脂質代謝にも或程 度關集するかも知れないと云つている。



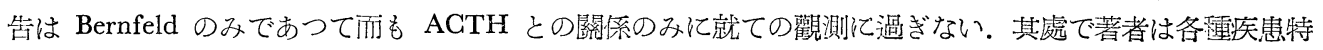
に本系成指と關原が密接である墸疾患们就て本系ホルモンとして ACTH のみならず Cortisone, DCAをも

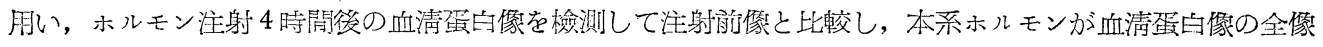

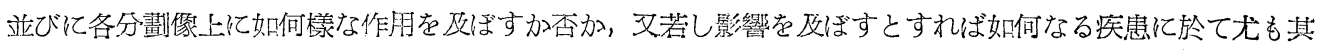
の影響を受ける事肪著明であるかの諸點に就て檢索して見ようと企てた。

\section{II 實驗材料及び賽驗方法}

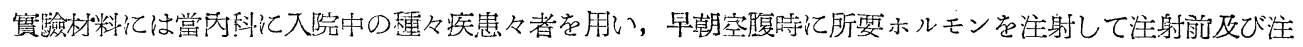

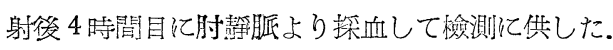

實驗䎲使用したホルモン製劑名及び其便用量は

ACTH : Acther (Armour) 20mg. Cortisone: Gortone acetate (Merck) 25mg 及び DGA: Syncorta 


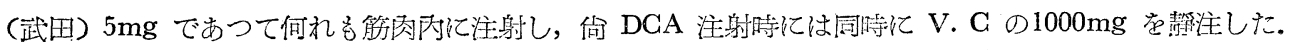

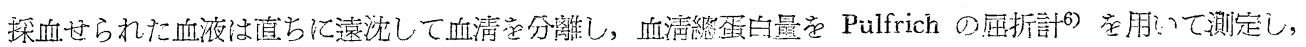

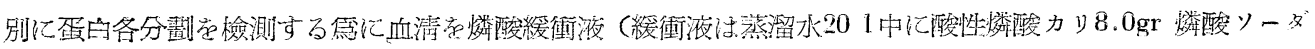

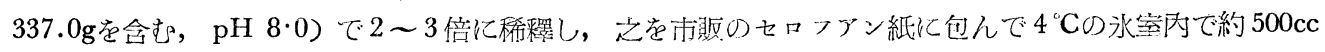
の燐酸䌅衝液中に24時間透析し，透析後の試料の蛋白濃度を $1.2 \sim 2.0 \mathrm{~g} / \mathrm{dl}$ とした。

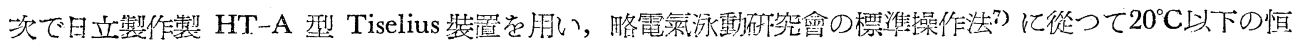

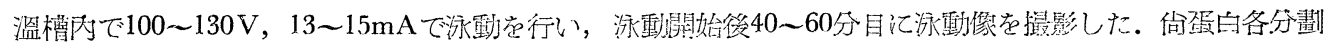

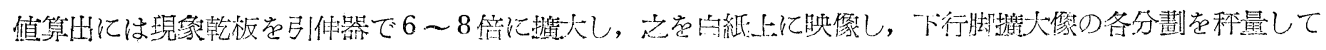
夫等の終對量を總蛋白量より算出した。

\section{III 檢 測 成 績}

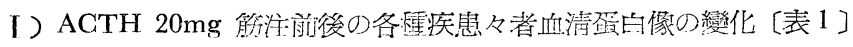

筑 1 焉 ACTH $20 \mathrm{mg}$ 注射前後の备種垁患々者血清蛋白像

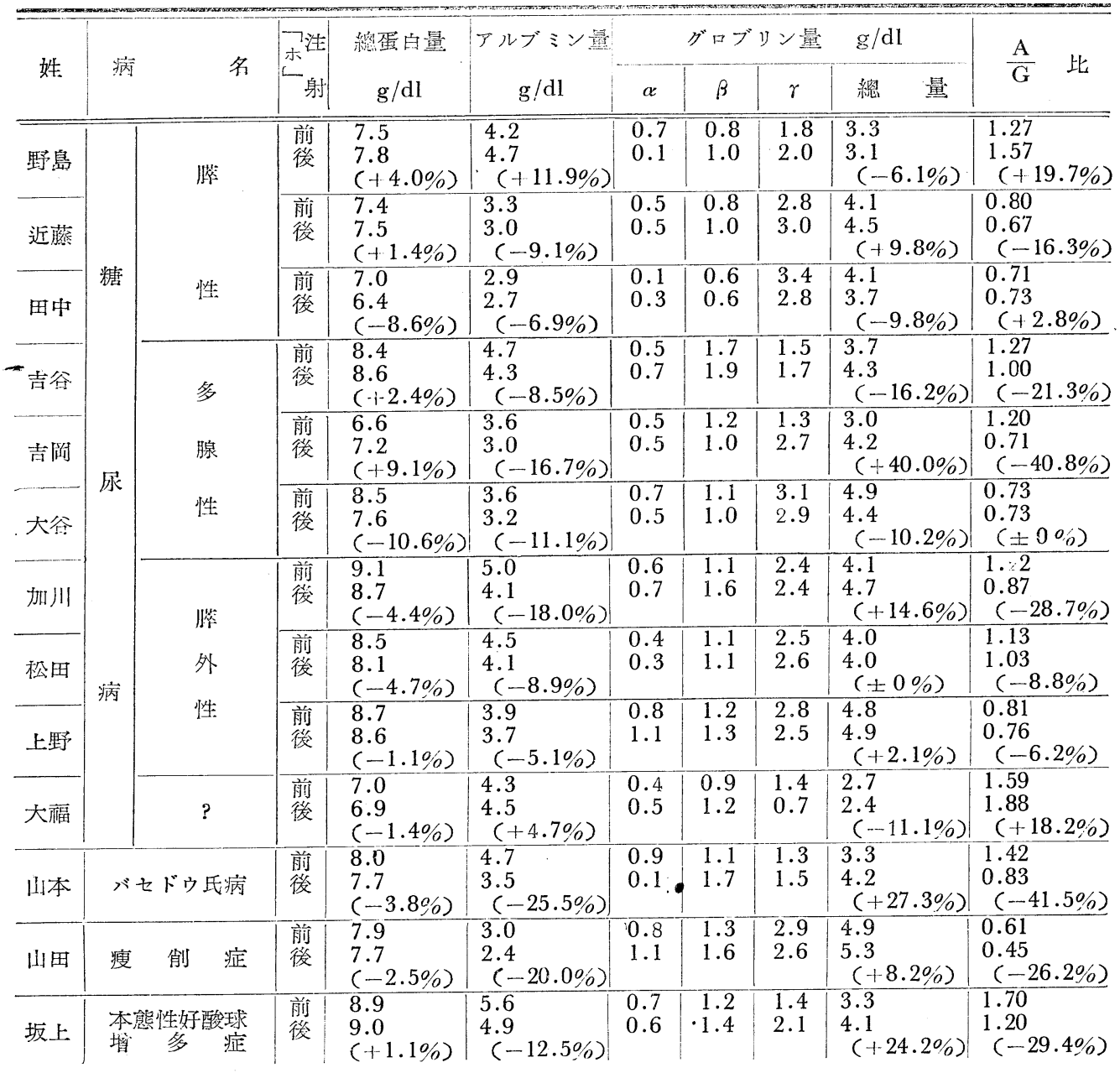




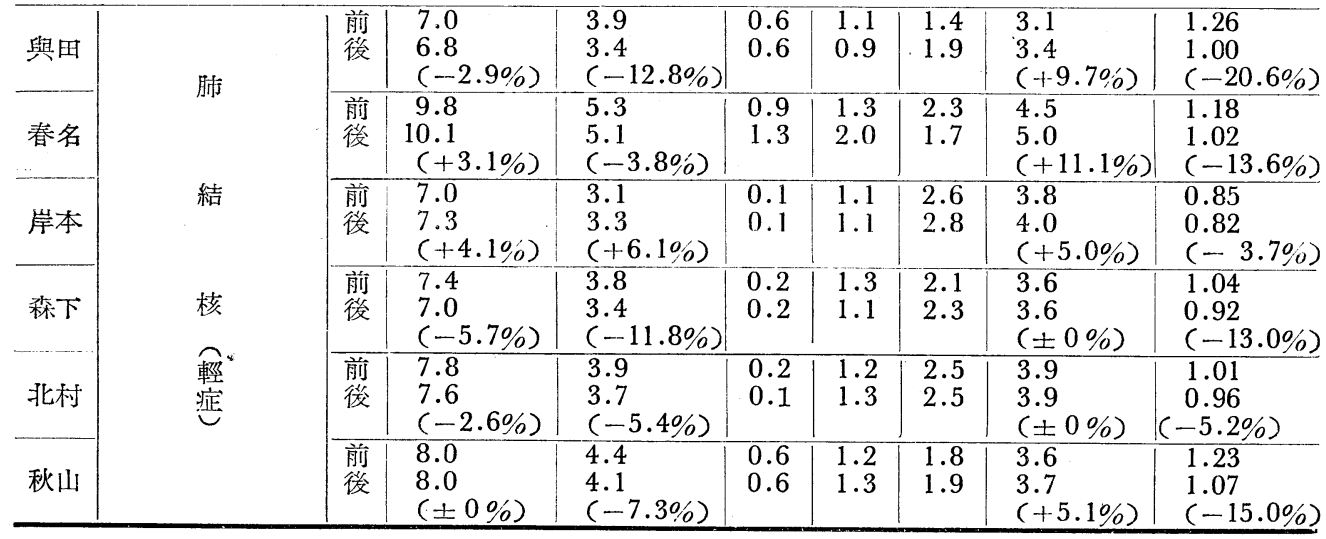

(A) ACTH 注射前後の總蛋白量, A量, G 量, 及び $\mathrm{A} / \mathrm{G}$ 比。

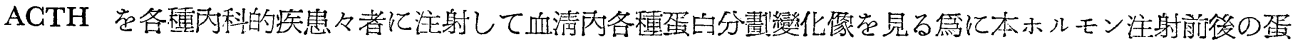
白各分劃㥧，減例數を（表1）汃ら拔き出して作つたのが（表 2) である.

第 2 表 ACTH 注射前後の血清蛋白像變化（例數）

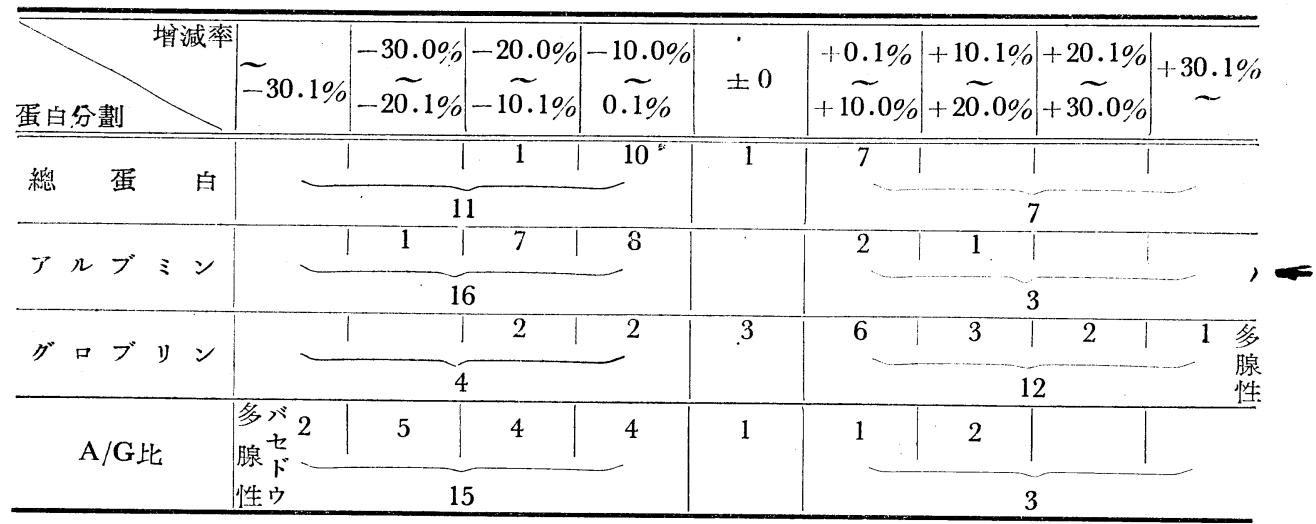

本表に依ると血清總蛋量は ACTH 注射により全例に其の變化は輕繁であつたが，概して減少の傾向を示 した.

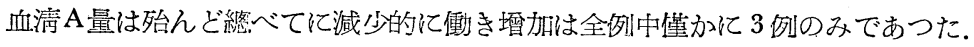

血淸 $\mathrm{G}$ 量は不變 3 例，增加12例，減少 4 例で總じて增加の傾向が見られた.

$\mathrm{A} / \mathrm{G}$ 比では減少15例, 墰加 3 例で大部分肪減少的に作用し, 特に Basedow 氏病と糖尿病中インシュリ ン微感性多腺性糖后病の各 1 例では $\mathrm{A} / \mathrm{G}$ 比が40\%以上の減少率を示しその減少が著明であつた。

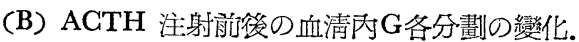

次に ACTH 注射時 $\mathrm{G}$ 各分劃 ( $\alpha-\mathrm{G}, \beta_{0} \mathrm{G}$ 邓び $\gamma-\mathrm{G}$ ) 量を便宜上 $\mathrm{G}$ 總量を 100 として各分劃の比率を算

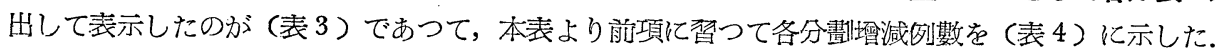

4 表を見ると，AGTH 注射により $\alpha-G$ で法減少例が，又 $\beta-G$ では增加例が多數を与めている， $\gamma-G$ は減少と恓加例が相生ばして居た．向 ACTH 注射前後差21以上の變動を示したのは2例であつて之等の例 では病種不明糖尿病の 1 例では減少, 多脉性糖巵病の 1 例では增加を示した。

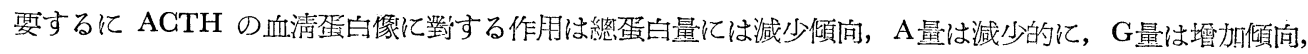
並びに $\mathrm{A} / \mathrm{G}$ 比は減少的，又各分劃では $\alpha-\mathrm{G}$ は隇少， $\beta-\mathrm{G}$ は堌加を示した例が多く見られた。疾患別 
第3表 ACTH 注射前後の各種疾患及者血淸内 グロブリン各分劃比)

(總グロブリン量を 100 とする)

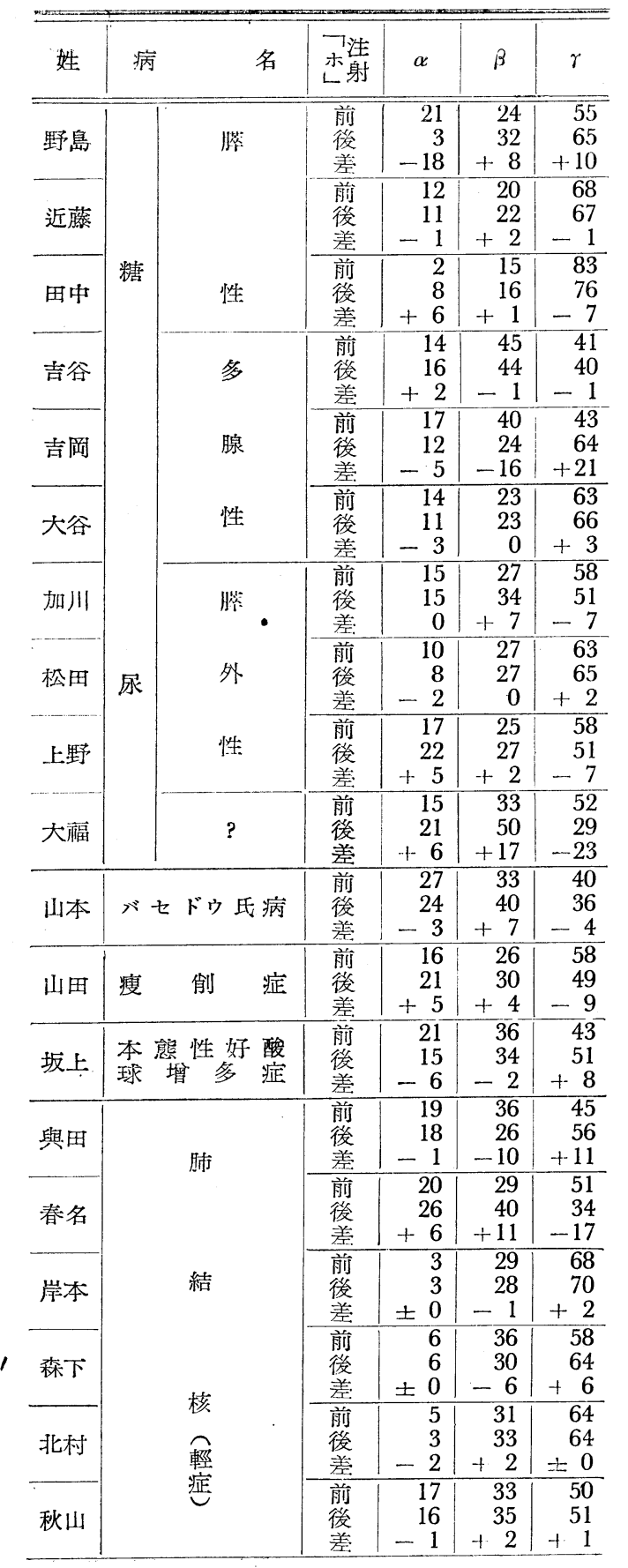

では A/G 比の著明な減少觉 Basedow 氏病と多 腺性程应病の备 1 例に於て見た。

II ) Cortisone $25 \mathrm{mg}$ 筋注勈後の各硾疾患々者 血清蛋白栠の變化（表 5 ）(表 6 )

A) Cortis 注射前後の總蛋白量, A量, G量, 及び A/G 比。

總趣白量に對する Cortis の作用は ACTH と 同樣に變化は輕徽であるが矢張り減少的に㗢いて いる.

血清 $\mathrm{A}$ 量は之も亦同樣減少の傾向力强い.

血清 $\mathrm{G}$ 量は不變 8 例, 筧加 9 例, 減少 4 例で輕 徵增加の傾问力゙見られ，從つて $\mathrm{A} / \mathrm{G}$ 比は減少を 示す例が多數であつた。而して $\mathrm{A} / \mathrm{G}$ 比が30.1\%

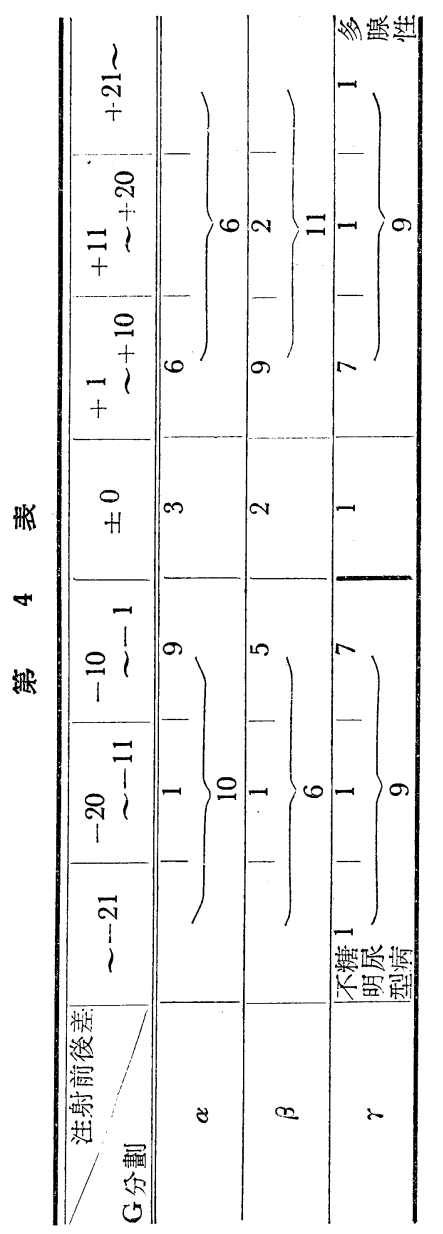




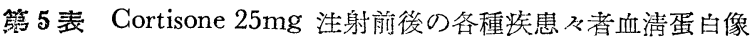

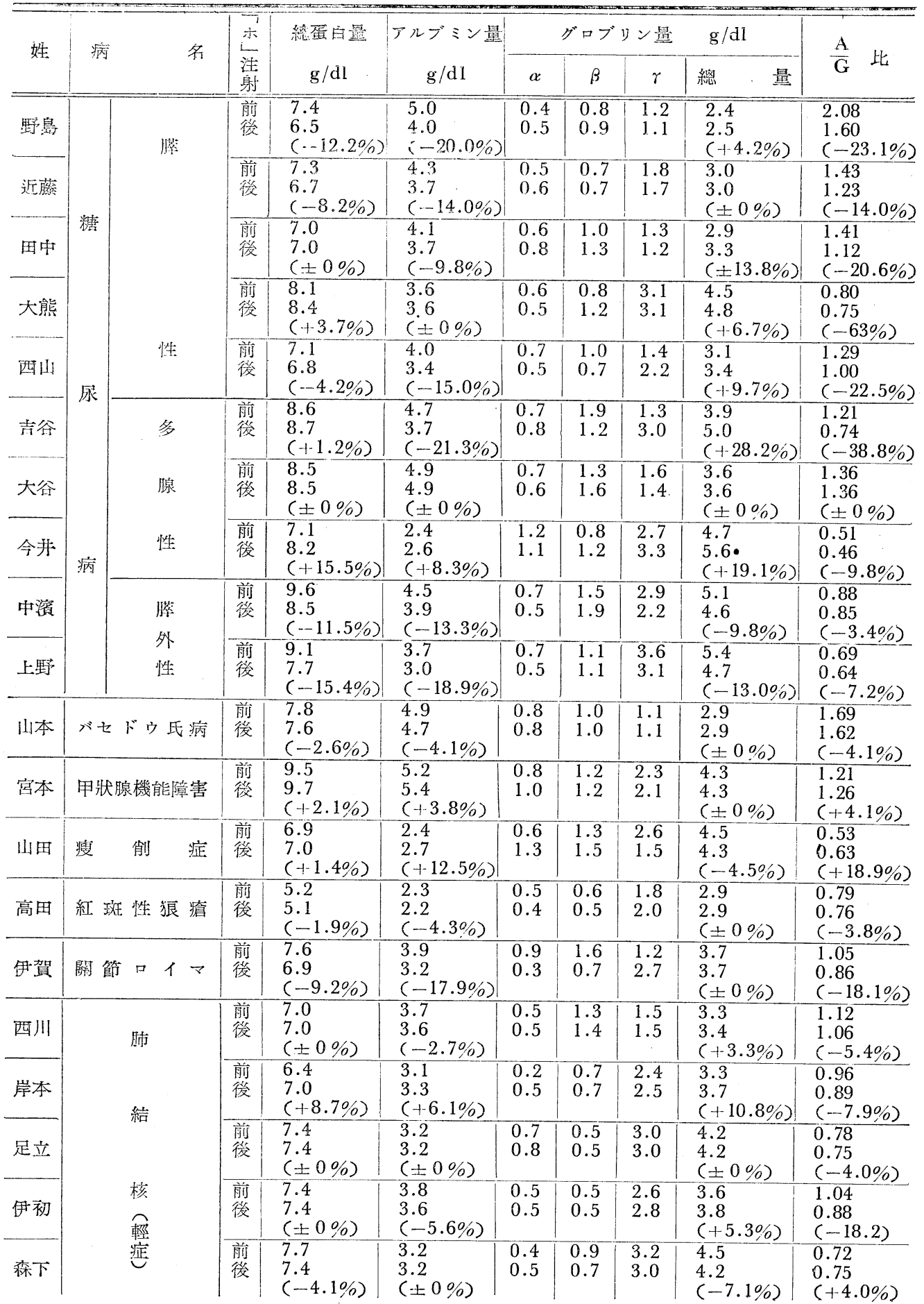




\begin{tabular}{l|l|l|l|l|l|l|l|l|l} 
& $\begin{array}{l}4.0 \\
\text { 前 }\end{array}$ & $\begin{array}{l}8.0 \\
\text { 後 }\end{array}$ & $\begin{array}{l}7.8 \\
(-2.6 \%)\end{array}$ & $\begin{array}{l}3.8 \\
(-5.3 \%)\end{array}$ & 0.5 & 1.3 & 2.4 & 4.0 & 1.01 \\
\hline
\end{tabular}

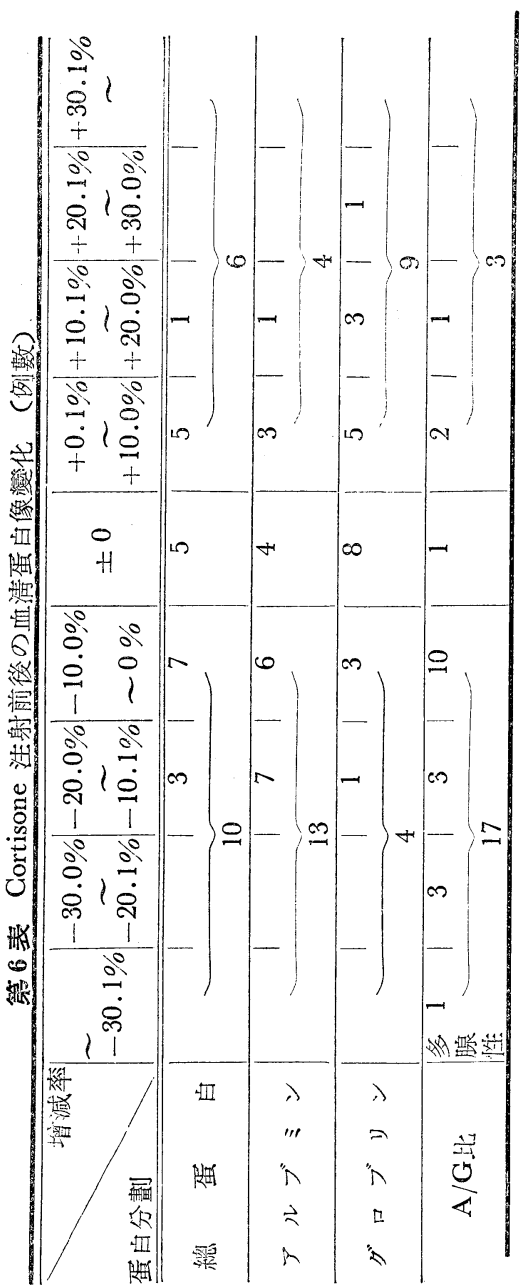

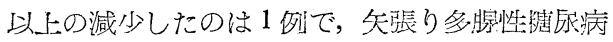
であつた。

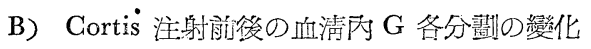
(表7)(䒾 8 )

Cortis 注射に依つて, $\alpha-\mathrm{G}$ は減少の傾向, $\beta-\mathrm{G}$ は增加の傾向が見られ， $\gamma-G$ では減少例が輕䱋 多數であつた，G各分劃像 $\beta-G$ は墂加例が多斯 であつたのに, 多腺性糖㽷病と關䈱口イマの各 1 例に於いて $\beta-G$ の著減方見られ，該 2 例认於い て $\boldsymbol{r}-\mathrm{G}$ の著增を證せられたの少矤患別坼見の異
第 7 表 Cortisone 注射前後の各種聅患及者血清 內グロブリン苔分劃此

(總グロブリン量を 100 とする)

\begin{tabular}{|c|c|c|c|c|c|c|}
\hline 姓 & \multicolumn{2}{|l|}{ 㾤 } & 兆洼 & $\alpha$ & $\beta$ & $\gamma$ \\
\hline 野息 & \multirow{5}{*}{ 栯 } & \multirow{3}{*}{ 櫒 } & $\begin{array}{l}\text { 前 } \\
\text { 後 } \\
\text { 差: }\end{array}$ & $\begin{array}{r}17 \\
20 \\
+\quad 3 \\
\end{array}$ & $\begin{array}{r}33 \\
36 \\
+\quad 3 \\
\end{array}$ & $\begin{array}{r}50 \\
44 \\
-\quad 6 \\
\end{array}$ \\
\hline 近藤 & & & $\begin{array}{l}\text { 前 } \\
\text { 後 } \\
\text { 差: }\end{array}$ & $\begin{array}{r}17 \\
20 \\
+\quad 3\end{array}$ & $\begin{array}{r}23 \\
23 \\
0\end{array}$ & $\begin{array}{r}60 \\
57 \\
-\quad 3\end{array}$ \\
\hline 田中 & & & $\begin{array}{l}\text { 前 } \\
\text { 後 } \\
\text { 逵 }\end{array}$ & $\begin{array}{r}21 \\
24 \\
+\quad 3 \\
\end{array}$ & $\begin{array}{r}34 \\
40 \\
+\quad 6\end{array}$ & $\begin{array}{r}45 \\
36 \\
-9\end{array}$ \\
\hline 大熊 & & \multirow[t]{2}{*}{ 性 } & $\begin{array}{l}\text { 前 } \\
\text { 後 } \\
\text { 美 }\end{array}$ & $\begin{array}{r}13 \\
10 \\
-\quad 3\end{array}$ & $\begin{array}{r}18 \\
25 \\
+\quad 7\end{array}$ & $\begin{array}{r}69 \\
65 \\
-\quad 4\end{array}$ \\
\hline 西山 & & & $\begin{array}{l}\text { 前 } \\
\text { 麸 } \\
\text { 差 }\end{array}$ & $\begin{array}{r}23 \\
15 \\
-\quad 8\end{array}$ & $\begin{array}{r}32 \\
20 \\
-12\end{array}$ & $\begin{array}{r}45 \\
65 \\
+20\end{array}$ \\
\hline 吉谷 & 尿 & 多 & $\begin{array}{l}\text { 前 } \\
\text { 後 } \\
\text { 差: }\end{array}$ & $\begin{array}{r}18 \\
16 \\
-\quad 2\end{array}$ & $\begin{array}{r}49 \\
24 \\
-25\end{array}$ & $\begin{array}{r}33 \\
60 \\
+27\end{array}$ \\
\hline 大谷 & \multirow{4}{*}{ 病 } & 腺 & $\begin{array}{l}\text { 前 } \\
\text { 後 } \\
\text { 善 }\end{array}$ & $\begin{array}{r}19 \\
17 \\
-\quad 2 \\
\end{array}$ & $\begin{array}{r}37 \\
44 \\
+\quad 7\end{array}$ & $\begin{array}{r}44 \\
39 \\
+\quad 5\end{array}$ \\
\hline 今抙 & & 性 & $\begin{array}{l}\text { 前 } \\
\text { 後 } \\
\text { 善 }\end{array}$ & $\begin{array}{r}26 \\
20 \\
-\quad 6 \\
\end{array}$ & $\begin{array}{r}17 \\
21 \\
+\quad 4 \\
\end{array}$ & $\begin{array}{r}57 \\
59 \\
+\quad 2 \\
\end{array}$ \\
\hline 中澒 & & \multirow{2}{*}{$\begin{array}{l}\text { 薈 } \\
\text { 外 } \\
\text { 性 }\end{array}$} & $\begin{array}{l}\text { 前 } \\
\text { 後 } \\
\text { 差 }\end{array}$ & $\begin{array}{r}14 \\
11 \\
-\quad 3\end{array}$ & $\begin{array}{r}29 \\
41 \\
+12\end{array}$ & $\begin{array}{r}57 \\
48 \\
-\quad 9\end{array}$ \\
\hline 上野 & & & $\begin{array}{l}\text { 前 } \\
\text { 後 } \\
\text { 差 }\end{array}$ & $\begin{array}{r}13 \\
11 \\
-\quad 2 \\
\end{array}$ & $\begin{array}{r}20 \\
23 \\
+\quad 3\end{array}$ & $\begin{array}{r}67 \\
66 \\
-\quad 1\end{array}$ \\
\hline 江本 & \multicolumn{2}{|c|}{ バセドウ氏病 } & $\begin{array}{l}\text { 前 } \\
\text { 後 } \\
\text { 善: }\end{array}$ & $\begin{array}{r}28 \\
28 \\
\pm \quad 0 \\
\end{array}$ & $\begin{array}{r}34 \\
34 \\
+\quad 0 \\
\end{array}$ & $\begin{array}{r}38 \\
38 \\
+\quad 0 \\
\end{array}$ \\
\hline 宮本 & \multicolumn{2}{|c|}{ 甲狀腺機能障害 } & $\begin{array}{l}\text { 前 } \\
\text { 後 } \\
\text { 差: }\end{array}$ & $\begin{array}{r}19 \\
23 \\
+\quad 4 \\
\end{array}$ & $\begin{array}{r}28 \\
28 \\
\pm \quad 0 \\
\end{array}$ & $\begin{array}{r}53 \\
49 \\
-\quad 4 \\
\end{array}$ \\
\hline 山田 & \multicolumn{2}{|r|}{ 症 } & $\begin{array}{l}\text { 前 } \\
\text { 後 } \\
\text { 器: }\end{array}$ & $\begin{array}{r}13 \\
30 \\
+17 \\
\end{array}$ & $\begin{array}{r}29 \\
35 \\
+\quad 6 \\
\end{array}$ & $\begin{array}{r}58 \\
35 \\
-23 \\
\end{array}$ \\
\hline 高田 & \multicolumn{2}{|c|}{ 紅斑 性狼 瘡 } & $\begin{array}{l}\text { 前 } \\
\text { 後 } \\
\text { 差: }\end{array}$ & $\begin{array}{r}17 \\
14 \\
-\quad 3 \\
\end{array}$ & $\begin{array}{r}21 \\
17 \\
-\quad 4 \\
\end{array}$ & $\begin{array}{r}62 \\
69 \\
+\quad 7 \\
\end{array}$ \\
\hline 伊賀 & 閣拿 節 & 口 17 & $\begin{array}{l}\text { 前 } \\
\text { 㷋 } \\
\text { 差 }\end{array}$ & $\begin{array}{r}24 \\
8 \\
-16 \\
\end{array}$ & $\begin{array}{r}43 \\
19 \\
-24 \\
\end{array}$ & $\begin{array}{r}33 \\
73 \\
+40\end{array}$ \\
\hline 西川 & \multirow{3}{*}{\multicolumn{2}{|c|}{ 脑 }} & $\begin{array}{l}\text { 前 } \\
\text { 後 } \\
\text { 差 }\end{array}$ & $\begin{array}{r}15 \\
15 \\
\pm 0\end{array}$ & $\begin{array}{r}39 \\
41 \\
+\quad 2\end{array}$ & $\begin{array}{r}46 \\
44 \\
-\quad 2\end{array}$ \\
\hline 岸本 & & & $\begin{array}{l}\text { 耐 } \\
\text { 㣭 } \\
\text { 差 }\end{array}$ & $\begin{array}{r}6 \\
14 \\
+\quad 8 \\
\end{array}$ & $\begin{array}{r}21 \\
19 \\
-\quad 2\end{array}$ & $\begin{array}{r}73 \\
67 \\
-\quad 6\end{array}$ \\
\hline 足立 & & & $\begin{array}{l}\text { 前 } \\
\text { 後 } \\
\text { 差 }\end{array}$ & $\begin{array}{r}17 \\
19 \\
+\quad 2\end{array}$ & $\begin{array}{r}12 \\
12 \\
\pm 0\end{array}$ & $\begin{array}{r}70 \\
70 \\
\pm \quad 0\end{array}$ \\
\hline
\end{tabular}


例であつた。

要するに，Cortis の血清蛋白儌に對する作用は $\mathrm{ACTH}$ の場合と殆んど同樣であつた，即ち兩ホ ルモン其に血清 $\mathrm{A}$ 量は減少的に，G量は增加的に 作用寸る (Cortis は ACTH ほど減少又は增加 例數比に對り，著明な差違を示さなかつたがう從つ

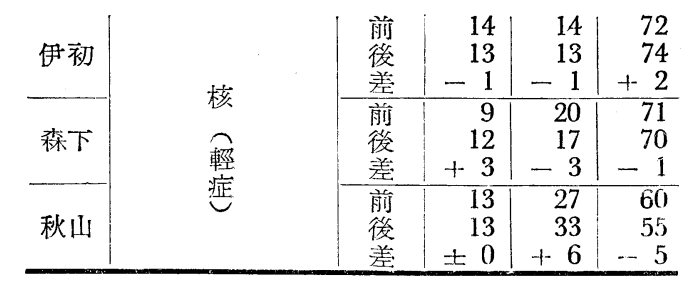

第 8 表

\begin{tabular}{|c|c|c|c|c|c|c|c|}
\hline G分劃 & $\sim-21$ & $\stackrel{-20}{\sim-11}$ & $\stackrel{-10}{\sim-1}$ & \pm 0 & $+\frac{1}{\sim+10}$ & $\stackrel{+11}{\sim+20}$ & $+21 \sim$ \\
\hline$\alpha$ & & 10 & 9 & 3 & 7 & 8 & \\
\hline$\beta$ & 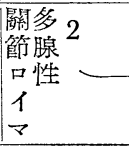 & $\underbrace{1}_{7}$ & 4 &, 4 & 9 & 10 & \\
\hline$\gamma$ & 瘦 1 & 12 & 11 & 2 & 4 & 1 & 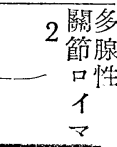 \\
\hline
\end{tabular}

第 9 表 DCA $5 \mathrm{mg}+\mathrm{V} . \mathrm{Cl} 100 \mathrm{mg}$ 注射前後の各種䛈患及者血清蛋白像

\begin{tabular}{|c|c|c|c|c|c|c|c|c|c|c|}
\hline \multirow{2}{*}{ 姓 } & \multirow{2}{*}{ 病 } & \multirow{2}{*}{ 名 } & \multirow{2}{*}{$\begin{array}{l}\text { 小 } \\
\text { 潗 } \\
\text { 射 }\end{array}$} & \multirow{2}{*}{$\begin{array}{c}\text { 總蛋白量 } \\
\text { g/dl }\end{array}$} & \multirow{2}{*}{$\begin{array}{c}\text { アルブミン量 } \\
\mathrm{g} / \mathrm{dl}\end{array}$} & \multicolumn{4}{|c|}{ グロブリン量 $\mathrm{g} / \mathrm{dl}$} & \multirow{2}{*}{$\frac{A}{G}$ 比 } \\
\hline & & & & & & $\alpha$ & $\beta$ & $\gamma$ & 總 & \\
\hline 吉谷 & \multirow[t]{2}{*}{ 糖 } & \multirow{2}{*}{$\begin{array}{l}\text { 多 } \\
\text { 腺 } \\
\text { 坚 }\end{array}$} & $\begin{array}{l}\text { 前 } \\
\text { 後 }\end{array}$ & $\begin{array}{l}8.2 \\
7.4 \\
(-9.8 \%)\end{array}$ & $\begin{array}{l}3.7 \\
3.5 \\
(-5.4 \%)\end{array}$ & $\begin{array}{l}0.7 \\
0.2\end{array}$ & $\begin{array}{l}1.5 \\
0.7\end{array}$ & $\begin{array}{l}2.3 \\
3.0\end{array}$ & $\begin{array}{l}4.5 \\
3.9 \\
(-13.3 \%)\end{array}$ & $\begin{array}{l}0.82 \\
0.90 \\
(+9.8 \%)\end{array}$ \\
\hline 吉閂 & & & $\begin{array}{l}\text { 前 } \\
\text { 後 }\end{array}$ & $\begin{array}{l}6.3 \\
6.7 \\
(+6.3 \%)\end{array}$ & $\begin{array}{l}2.6 \\
3.1 \\
(+19.2 \%)\end{array}$ & $\begin{array}{l}0.5 \\
0.7\end{array}$ & $\begin{array}{l}1.0 \\
1.1\end{array}$ & $\begin{array}{l}2.2 \\
1.8\end{array}$ & $\begin{array}{l}3.7 \\
3.6 \\
(-2.7 \%)\end{array}$ & $\begin{array}{l}0.70 \\
0.86 \\
(+22.9 \%)\end{array}$ \\
\hline 松田 & 尿 & \multirow{2}{*}{$\begin{array}{l}\text { 櫒 } \\
\text { 外 } \\
\text { 性 }\end{array}$} & $\begin{array}{l}\text { 前 } \\
\text { 後 }\end{array}$ & $\begin{array}{l}8.5 \\
6.6 \\
(-22.4 \%)\end{array}$ & $\begin{array}{l}4.0 \\
3.3 \\
(-17.5 \%)\end{array}$ & $\begin{array}{l}0.6 \\
0.4\end{array}$ & $\begin{array}{l}0.7 \\
0.7\end{array}$ & $\begin{array}{l}3.2 \\
2.2\end{array}$ & $\begin{array}{l}4.5 \\
3.3 \\
(-26.7 \%)\end{array}$ & $\begin{array}{l}0.89 \\
1.00 \\
(+12.4 \%)\end{array}$ \\
\hline 栗山 & 病 & & $\begin{array}{l}\text { 前 } \\
\text { 後 }\end{array}$ & $\begin{array}{l}6.3 \\
6.4 \\
(+1.6 \%)\end{array}$ & $\begin{array}{l}2.5 \\
2.8 \\
(+12.0 \%)\end{array}$ & $\begin{array}{l}1.0 \\
0.7\end{array}$ & $\begin{array}{l}1.1 \\
0.8\end{array}$ & $\begin{array}{l}1.1 \\
1.7\end{array}$ & $\begin{array}{l}3.2 \\
3.2 \\
( \pm 0 \%)\end{array}$ & $\begin{array}{l}0.97 \\
1.00 \\
(+3.1 \%)\end{array}$ \\
\hline 山田 & 瘦 & 制，症 & $\begin{array}{l}\text { 前 } \\
\text { 後 }\end{array}$ & $\begin{array}{l}6.6 \\
7.2 \\
(+9.1 \%)\end{array}$ & $\begin{array}{l}2.6 \\
4.0 \\
(+53.8 \%)\end{array}$ & $\begin{array}{l}0.7 \\
0.6\end{array}$ & $\begin{array}{l}1.0 \\
1.0\end{array}$ & $\begin{array}{l}2.4 \\
2.8\end{array}$ & $\begin{array}{l}4.1 \\
4.4 \\
(+7.3 \%)\end{array}$ & $\begin{array}{l}0.61 \\
0.64 \\
(+4.9 \%)\end{array}$ \\
\hline 高田 & \multicolumn{2}{|c|}{ 紅 斑 性狼瘡 } & $\begin{array}{l}\text { 前 } \\
\text { 後 }\end{array}$ & $\begin{array}{l}5.5 \\
6.8 \\
(+23.6 \%) \\
\end{array}$ & $\begin{array}{l}3.7 \\
3.4 \\
(-8.1 \%)\end{array}$ & $\begin{array}{l}1.0 \\
0.7\end{array}$ & $\begin{array}{l}0.5 \\
0.8\end{array}$ & $\begin{array}{l}1.4 \\
1.3\end{array}$ & $\begin{array}{l}2.9 \\
2.8 \\
(-3.4 \%)\end{array}$ & $\begin{array}{l}0.90 \\
1.43 \\
(+58.9 \%)\end{array}$ \\
\hline 柳谷 & \multicolumn{2}{|c|}{ 結核 性腹膜 炎 } & $\begin{array}{l}\text { 前 } \\
\text { 後 }\end{array}$ & $\begin{array}{l}4.4 \\
4.6 \\
(+4.5 \%)\end{array}$ & $\begin{array}{l}1.9 \\
1.5 \\
(-21.1 \%)\end{array}$ & $\begin{array}{l}0.5 \\
0.8\end{array}$ & $\begin{array}{l}0.8 \\
1.0\end{array}$ & $\begin{array}{l}1.2 \\
1.3\end{array}$ & $\begin{array}{l}2.5 \\
3.1 \\
(+24.0 \%)\end{array}$ & $\begin{array}{l}0.76 \\
0.48 \\
(-36.8 \%)\end{array}$ \\
\hline 藤原 & \multicolumn{2}{|r|}{ 肺 } & $\begin{array}{l}\text { 前 } \\
\text { 後 }\end{array}$ & $\begin{array}{l}8.7 \\
8.1 \\
(-6.9 \%)\end{array}$ & $\begin{array}{l}3.7 \\
3.4 \\
(-8.1 \%)\end{array}$ & $\begin{array}{l}0.4 \\
0.8\end{array}$ & $\begin{array}{l}0.9 \\
0.9\end{array}$ & $\begin{array}{l}3.7 \\
3.0\end{array}$ & $\begin{array}{l}5.0 \\
4.7 \\
(-6.0 \%)\end{array}$ & $\begin{array}{l}0.74 \\
0.72 \\
(-2.70 \%)\end{array}$ \\
\hline 岸本 & \multirow{3}{*}{\multicolumn{2}{|c|}{$\begin{array}{l}\text { 結 } \\
\text { 核 } \\
\text { 輕 } \\
\text { 症 }\end{array}$}} & $\begin{array}{l}\text { 前 } \\
\text { 後 }\end{array}$ & $\begin{array}{l}6.8 \\
6.9 \\
(+1.4 \%)\end{array}$ & $\begin{array}{l}3.0 \\
3.2 \\
(+6.3 \%)\end{array}$ & $\begin{array}{l}0.4 \\
0.3\end{array}$ & $\begin{array}{l}1.0 \\
1.0\end{array}$ & $\begin{array}{l}2.3 \\
2.3\end{array}$ & $\begin{array}{l}3.8 \\
3.6 \\
(-5.6 \%)\end{array}$ & $\begin{array}{l}0.79 \\
0.89 \\
(+11.2 \%)\end{array}$ \\
\hline 森下 & & & $\begin{array}{l}\text { 前 } \\
\text { 後 }\end{array}$ & $\begin{array}{l}7.0 \\
7.0 \\
( \pm 0 \%)\end{array}$ & $\begin{array}{l}3.2 \\
3.1 \\
(-3.2 \%)\end{array}$ & $\begin{array}{l}0.2 \\
0.3\end{array}$ & $\begin{array}{l}1.0 \\
0.9\end{array}$ & $\begin{array}{l}2.6 \\
2.7\end{array}$ & $\begin{array}{l}3.8 \\
3.9 \\
(+2.6 \%)\end{array}$ & $\begin{array}{l}0.85 \\
0.81 \\
(-4.9 \%)\end{array}$ \\
\hline 足立 & & & $\begin{array}{l}\text { 前 } \\
\text { 後 }\end{array}$ & $\begin{array}{l}7.2 \\
7.0 \\
(-2.9 \%)\end{array}$ & $\begin{array}{l}3.4 \\
3.5 \\
(+2.9 \%)\end{array}$ & $\begin{array}{l}0.5 \\
0.3\end{array}$ & $\begin{array}{l}1.3 \\
1.1\end{array}$ & $\begin{array}{l}2.0 \\
2.1\end{array}$ & $\begin{array}{l}3.8 \\
3.5 \\
(+2.6 \%)\end{array}$ & $\begin{array}{l}0.85 \\
0.81 \\
(-4.9 \%)\end{array}$ \\
\hline
\end{tabular}


第10表 $\mathrm{DCA}+\mathrm{V} . \mathrm{C}$ 注射前後の血洘蛋白像變化（例㫋）

\begin{tabular}{|c|c|c|c|c|c|c|c|c|c|}
\hline 蛋白分劃 & $\widetilde{\sim} 30.1 \%$ & $\begin{array}{l}-30.0 \% \\
-20.1 \% \\
\end{array}$ & $\mid \begin{array}{l}-20.0 \% \\
-10.1 \%\end{array}$ & $\begin{array}{l}-10.0 \% \\
-0.1 \%\end{array}$ & $\pm 0 \%$ & $\begin{array}{l}+0.1 \% \\
+10.0 \%\end{array}$ & $\begin{array}{r}+10.1 \% \\
+20.0 \% \\
\end{array}$ & $\begin{array}{l}+20.1 \% \\
+30.0 \% \\
\end{array}$ & $\sim 30.1 \%$ \\
\hline & & & 1 & 3 & \multirow{3}{*}{$\cdot$} & 5 & 1 & & \\
\hline 日 & \multicolumn{4}{|c|}{4} & & \multicolumn{4}{|c|}{6} \\
\hline \multirow{2}{*}{ 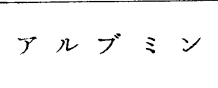 } & & 1 & 1 & \multirow[t]{2}{*}{3} & & 3 & 2 & T & 1 狼 \\
\hline & & & 5 & & & \multicolumn{4}{|c|}{6} \\
\hline \multirow{2}{*}{ グロブリン } & & 1 & 1 & \multirow[t]{2}{*}{5} & \multirow[t]{2}{*}{1} & 2 & T & 1 & \\
\hline & \multicolumn{3}{|l|}{ I0 } & & & \multicolumn{4}{|c|}{3} \\
\hline \multirow{2}{*}{$\frac{\mathrm{A}}{\mathrm{G}}$ 比 } & 腹 1 & & T & \multirow[t]{2}{*}{2} & & 3 & 3 & 1 & \multirow[t]{2}{*}{1 狼 } \\
\hline & 照 & & 3 & & & & 8 & & \\
\hline
\end{tabular}

て $\mathrm{A} / \mathrm{G}$ 比の減少を多数例に見， $\mathrm{G}$ 分劃葟では $\alpha-\mathrm{G}$ の減少と $\beta-\mathrm{G}$ の塤加傾问を認められた。 只兩ホルェン間の作用相賞としては，ACTH で はケ-G に變化を見られなかつたのに，Cortis で は其減少か證せられたという點であつた。

III) DGA $5 \mathrm{mg}$ (筋注) + V. G1000mg (繁 注) 注射前後の备霍疾患々者血淸蛋白傺の變化 (表 9 )

A) DCA + V. G 注射前後の總题白量, A 量，G量 及び $\mathrm{A} / \mathrm{G}$ 比（表10）

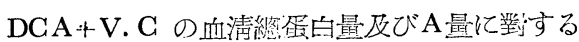
作用は減少的に働く瑒合と哂加的に働く場合とが 相牛ばして特䔬集を認められなかつたが，血清 $\mathrm{G}$ では不變 1 例, 増加 3 例, 減少 7 例で㮐々減少の 傾向力゙，又 $\mathrm{A} / \mathrm{G}$ 比は減少 3 例, 增加 8 例で倯々 增加の傾向が見られた。侗打特に紅斑性痕瘡患者

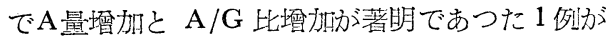
あつた。

B) $\mathrm{DGA}+\mathrm{V} \cdot \mathrm{G}$ 注射前後の血淸內 $\mathrm{G}$ 各分劃骤 の變化（表11)（表12）

血淸內 $\mathrm{G}$ 各分劃俉では， $\beta-\mathrm{G}, \gamma-\mathrm{G}$ 分劃共に墂 減例數殆んど同數で特異な䦎係は認められなかつ たが， $\alpha-\mathrm{G}$ は多數例にその減少を認めた。而し て本ホルモン注射依つて多腺性糖辰病で $\gamma-\mathrm{G}$ の著增を見た 1 例があつた。

$\mathrm{DCA}+\mathrm{V} . \mathrm{C}$ か $\mathrm{ACTH}$ やCortis と罳る點は A/G 比が ACTH 更び Cortis 作用に於て減少
管11表 $\mathrm{DCA}+\mathrm{V} . \mathrm{C}$ 注射前後の备種疾患々者血 清內各グロブリン分劃比

（總グロブリン量と 100 とする）

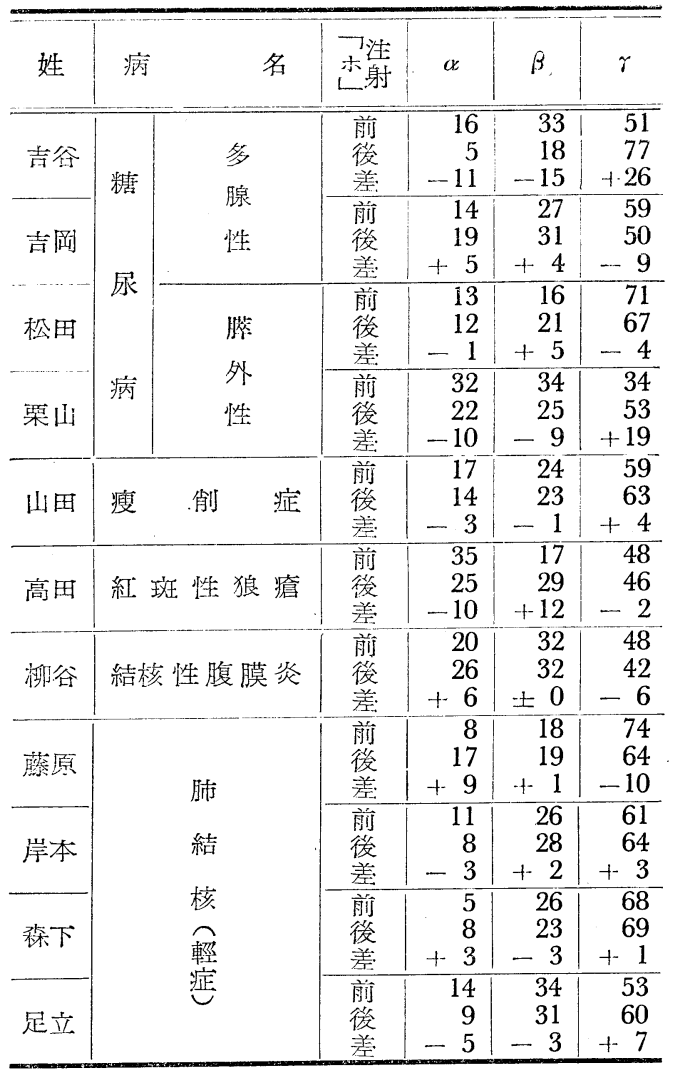

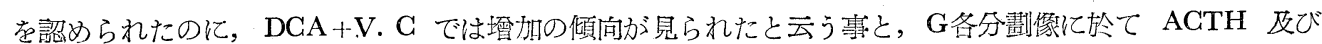
Cortis で $\beta-G$ の增加が認められたが， DGA +V. G では特買關係嗦を認められなかつたと云う事の 2 點 である。 
管 12 表

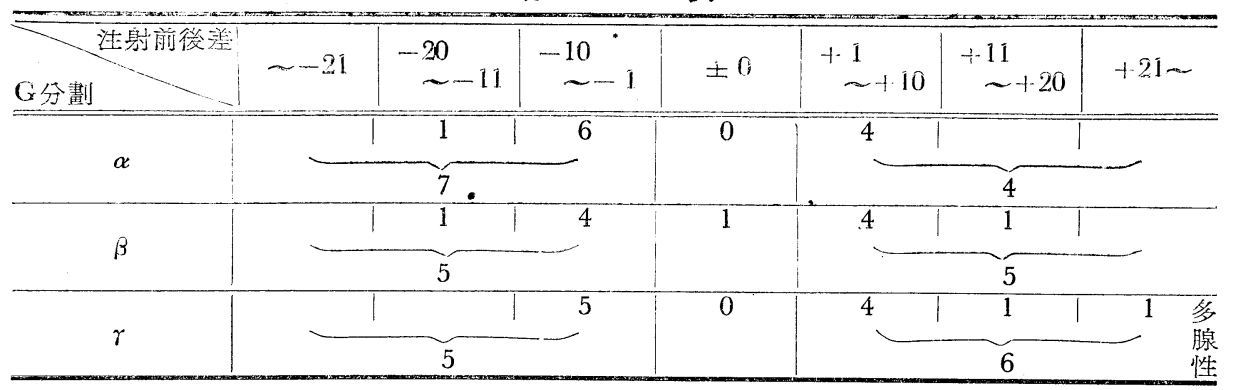

IV 綜 括

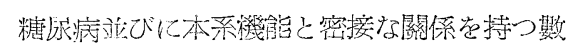

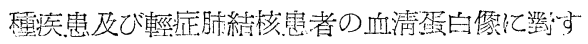
る下垂體前琵，副緊皮質系ホルモンの作用を檢 蔡した結果

1） 3 整ホルモン其に血清總蛋白量に對する 作用は輕徽であつたが，概して AGTH 妏び Cortis は減少的に，DGA +V.G では穛々䁲加 的働く場合が多加つた.

2) ACTH, Cortis は共に血暳A量には減少 的に，血清 $\mathrm{G}$ 量には增加的に作用し，從つて $\mathrm{A} / \mathrm{G}$ 此は減少を示す例が多數であつた。 DGA +V.G 作用には血清 $\mathrm{G}$ 量の減少, 從つて A/G 此を霄加せしむる傾向力見られた。

3） $\mathrm{G}$ 冬分劃售中 $\beta-G$ に監し $\mathrm{AGTH}$ 及び Cortis は墂加的に作朋した例が多く見られた。
筑 13 表

\begin{tabular}{|c|c|c|c|c|}
\hline 姓 & 病 & 種 & Thorn's Test & $\begin{array}{l}\text { インシュリン } \\
\text { 敏 感 }\end{array}$ \\
\hline 野 島 & \multirow{5}{*}{ 糖 } & 㭀 & -47.0 & -50.0 \\
\hline 近 藤 & & & -27.0 & -53.4 \\
\hline 田 中 & & 性 & -70.4 & -41.0 \\
\hline 大 熊 & & 多 & - & -59.3 \\
\hline 四 山 & & & -24.0 & -50.0 \\
\hline 吉 谷 & \multirow{3}{*}{ 尿 } & 腺 & -20.2 & -66.6 \\
\hline 大 谷 & & & -32.0 & -59.3 \\
\hline 今 并 & & 性 & - & -48.0 \\
\hline 中 濱 & \multirow{5}{*}{ 病 } & 䑏 & -60.8 & -32.3 \\
\hline 上 野 & & & -30.7 & -37.0 \\
\hline 加 川 & & 外 & -34.0 & -23.5 \\
\hline 松 田 & & 性 & -50.0 & -21.1 \\
\hline 大 福 & & ? & -36.0 & -51.0 \\
\hline
\end{tabular}

4） DCA +V.C が血清蛋白像に對する作用上で ACTH 及び Cortis と相違する點は，A/G 比とG各 分劃侄中の $\beta-G$ に對する作用に於てであつた。

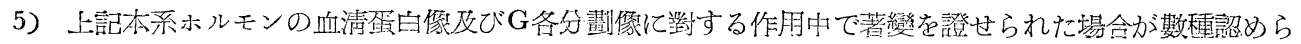
れた. 郎ち Basedow 氏病と多腺性糖尿病の各 1 例に於ける ACTH 作朋による A/G 比の著減，多腺性糖 㽷病の 1 例に於ける Cortis 作とよる $\mathrm{A} / \mathrm{G}$ 比の著減, 同 Cortis 作用による多腺性鈢家病及び關節口イマ

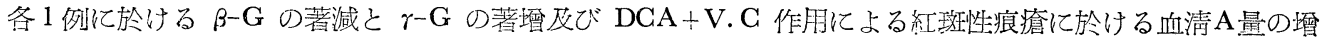

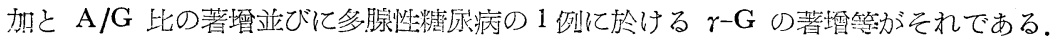

6）13列の糖尿病各病種中で本系ホルモンによつて血清蛋白像に蔁變を證せられたのは, 何れも多腺性糖

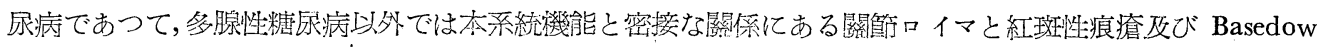
氏病とに於いて其の著變を證せられた。

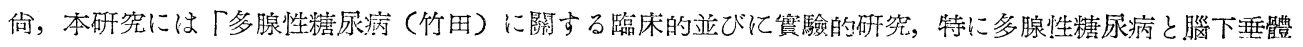
前烡，副腎皮質系ホルモンとの關係」の部分的研究として交部省より科學斫究費の交附を受けや。

\section{參考文献}

1) Long, Katzin e Fry: Endocrin. 26, 3091940

2) Goldberg: Compt. rend. Soc. Biol. 128, 1135,1938 3) Goldberg: Rev. Soc. Arg. Biol. 14, 49, 1938

4) Levine, Leathem: Am. J. Physiol. 136, 306, 1942 5) Bernfeld,Bouner \& Homburger: Proc. of 2nd Clin. ACTH Confer., Blakiston Co. 1, 2821951

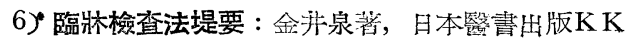
7) 電氣泳動䃝究會 : 昭 25, Tiselius 電氣泳動法實施規定 